\title{
Shaanxi Business Environment Construction under the National Strategy of "Belt and Road"
}

\author{
Lixiao Wang \\ Xi'an Fanyi University, Xi’an, Shaanxi, 710105
}

Keywords: The Belt and Road; environment construction; Shaanxi business

\begin{abstract}
With the implementation of the "The Belt and Road" strategy, a new pattern of Chinese all-round opening-up is gradually taking shape. Under the new situation, the internal and external environment of the opening-up of the western region has undergone major changes. Innovating the opening-up mechanism of the western region is a major trend to deeply integrate into the Belt and Road construction. The western region cannot simply replicate the experience of coastal areas. It should deepen the reform of investment and trade facilitation, improve the two-way investment layout mechanism, strengthen the financial innovation mechanism, expand the new space for opening-up, build a multi-level open-door cooperation mechanism to innovate, and comprehensively improve the level of opening-up to the outside world.
\end{abstract}

\section{Introduction}

After more than 30 years of reform and opening up, Chinese opening up to the outside world is realizing a major shift from introduction to introduction and going out, and a new situation of deep integration of market, resources, energy and investment has emerged. The construction of The Belt and Road is a profound change in the direction of the international situation under the new situation. It is based on the domestic market, attaches importance to the two major domestic and international situations, and promotes the major strategic decisions made by the outside world in an all-round way. It is the most comprehensive under the new historical conditions. Sexual national open strategy. The "The Belt and Road" strategy is a major change in Chinese regional economic development from the "unbalanced" strategy to the "balanced" strategy. It is a major adjustment of the focus of Chinese regional opening strategy, and has built a new round of "one body and two wings" for Chinese opening up to the outside world. It has fundamentally changed the economic and geographical location of the western region. While raising the level of openness in the east, it has also accelerated the pace of opening up to the west and shaped a new pattern of opening up to the outside world.

\section{Chinese Free Trade Zone Service Supports the Functional Attributes and Internal Relations of the Belt and Road}

Although the China Free Trade Zone and The Belt and Road have different international legal attributes, one is a typical FTZ, and the other is a free trade zone network. There are certain differences in system design, management mode, and governance structure. However, Chinese free trade. The district has the same strategic background and historical mission as The Belt and Road. Both strategies are designed to adapt to the new political and economic structure of the world, adjust and transform the domestic economic structure, break the economic blockade and political isolation in Europe and the United States, and make scientific decisions by the Party Central Committee. Reflecting the grand vision of the wisdom of the Chinese nation, there are inherent commonalities and connections between the two strategies.

The most important part of the innovation of the free trade zone system is the innovation of cultural industry system and the innovation of economic and trade management system. With the help of cultural industry and economic and trade management system innovation, it can effectively reduce institutional barriers in international trade, accelerate the free flow of international market 
elements, and promote the "one area”. All the way along the line of cultural exchanges and economic cooperation between countries, this is the "software" docking between the two strategies. In terms of hardware, the most important for the two strategic docking is the integration and connection of infrastructure. The establishment of a free trade zone in the transportation hub along The Belt and Road can give full play to the "The Belt and Road" free trade characteristics. Conducive to the realization of the interconnection of the two strategic geographical transportation. In 2017, the central government officially approved the establishment of the Henan and Shaanxi Free Trade Zones, precisely because the two places are located in the land transportation hub of The Belt and Road, which is the core of the "Haisi Road" with the Fujian Free Trade Zone. Similar to the region, the three places are the sea and land transportation hubs and gathering points along The Belt and Road. The free trade zones in Henan, Shaanxi and Fujian can effectively accelerate and enhance The Belt and Road freedom by virtue of institutional innovation and their outstanding geographical advantages. The transportation of goods, the transit of logistics, and the efficiency of passenger transportation and distribution have greatly reduced and reduced the time, manpower and material costs required for cross-border trade along The Belt and Road, which in turn facilitates the rapid development of the "The Belt and Road" free trade network. Formation and development. It is not difficult to find that the China Free Trade Zone is a functional attribute of the "The Belt and Road" strategy with service support through the hardware and software docking between the two strategies.

The China Free Trade Zone is connected to the strategic concept of "The Belt and Road". The "The Belt and Road" advocates "policy communication, road connectivity, smooth trade, currency circulation and popular support" and the "investment liberalization, trade marketization, financial internationalization, and management standardization” that Chinese free trade zone construction has always followed. There are many similarities, such as the standardization of policy communication and management, the smooth flow of trade to trade marketization, and the currency circulation corresponding to financial internationalization. The China Free Trade Zone and The Belt and Road also contain the spirit of mutual benefit and mutual benefit and win-win. The value concept of cooperation for mutual development.

The China Free Trade Zone has an intrinsic link with the strategic value of The Belt and Road. The core principle of "The Belt and Road" is to open up new market space by "going out", realize Chinese economic transformation, upgrading and rebalancing, and deepen the economic cooperation along the line by constructing a developed transportation network, and strive to create freedom with The Belt and Road as the carrier. Trade area network. As an important window for reform and opening up in the new era, Chinese free trade zone has the mission of eliminating trade barriers, promoting trade freedom, and enhancing trade facilitation. It also has the same function as “The Belt and Road" to enhance foreign trade and economic cooperation, expand opening up, and strengthen foreign exchanges. . The implementation of The Belt and Road free trade zone network requires some trade core areas along the line as regional nodes and strategic support, while the China Free Trade Zone is mostly located in The Belt and Road domestic line segment. The location advantage is significant, economic and trade exchanges are frequent, and the hinterland is relatively The vast transportation hub, coupled with its relaxed and convenient market management model, will undoubtedly become the best strategic cut-off point for China to link The Belt and Road free trade zone network. It is better able to pass the "The Belt and Road" free trade zone network of China Free Trade Zone. Effectively exerting the "The Belt and Road" factor aggregation, economic radiation and regional joint action, which is also in line with the meaning of the "The Belt and Road" free trade zone network.

China Free Trade Zone is an innovation of the "The Belt and Road” strategy incubation system. China Free Trade Zone is committed to promoting various management system innovations. The "first-in-first-trial" system provides a reliable practical platform and rich normative sources for the construction of The Belt and Road system, creating conditions and accumulating experience for the future "The Belt and Road" system construction. The Belt and Road will build a new platform for opening up to deepen bilateral economic cooperation with countries along the route, while the free 
trade zone will experiment with institutional innovation in terms of investment liberalization, trade facilitation, financial internationalization, and administrative management simplification. Accumulating experience in the transformation and upgrading of the domestic economy and participating in international trade negotiations is also conducive to the formation and development of a good rule of law business environment for The Belt and Road.

\section{Shaanxi Pilot Free Trade Zone to Create the "Belt and Road" Innovation Capital}

Establish a system for recording, publicizing, sharing and using credit information of market entities in the Pilot Free Trade Zone, implement a linkage mechanism for trustworthiness and disciplinary action; strengthen risk analysis, sort out regulatory risk points and prevention and control measures, and study the list of risk prevention and control bottom lines. Further clarify the regulatory responsibilities of each department. We will vigorously promote the joint taxation of national and local taxes and the taxation model of "one person, one machine, two systems and one POS". With "Internet +", we will improve service efficiency, optimize service processes, and develop and promote handheld service products such as WeChat tax. The national tax and local tax will be formulated to integrate the electronic tax bureau construction plan for the business of both parties to improve the efficiency of tax service. The national tax combined with the use of tax big data, etc., implements "one network" management of taxpayer tax information, and relies on the provincial social credit information platform to realize the sharing and utilization of taxpayer credit information and major tax illegal information among various departments. Establish an intellectual property operation service center. Relying on the State Council for the Promotion of International Trade and the Supreme People's Court to jointly establish The Belt and Road commercial arbitration and mediation center in the Pilot Free Trade Zone to attract relevant legal service formats and build a "The Belt and Road" central legal service area to create a good construction for the free trade pilot zone. The rule of law environment.

Adhere to problem-oriented and enterprise demand orientation, explore institutional innovation, and promote differentiated reform as a key work in the construction of Shaanxi Pilot Free Trade Zone. The various areas of Shaanxi Pilot Free Trade Zone and various functional areas have been summarized in the process of exploring and innovating. 58 cases with innovative features, evaluated by third-party accreditation bodies, 32 innovative, 19 of which are more mature cases (4 commercial system reforms, 2 trade facilitation projects, 2 financial innovations, military-civilian integration 2 The project, three agricultural projects, and five countries along The Belt and Road economic cooperation and humanities exchanges have been piloted in various functional areas. At the same time, the management committees and functional areas of the Pilot Free Trade Zone have combined their own functional positioning and industrial characteristics, and successively introduced the preferential policies for attracting investment and attracting talents. The Provincial Department of Commerce (FTTA) actively built a new platform for attracting investment, and organized a Sino-Japanese project cooperation seminar in Beijing and Shanghai, and a promotion conference on investment environment and key projects in the China (Shaanxi) Pilot Free Trade Zone, organized in Xi'an. The Shaanxi-Singapore Economic and Trade Cooperation Fair invited the American Chamber of Commerce in China to participate in the inspection and exchanges from the Trade Experimental Zone and reached a number of cooperation intentions.

Accelerate the promotion of the optimization of technology, talents and capital elements in the Pilot Free Trade Zone. The Shaanxi Pilot Free Trade Zone promoted the reform and innovation of the investment system and formulated and promulgated the "Administrative Measures for the Approval and Filing of Enterprise Investment Projects in Shaanxi Province”, which effectively promoted the enterprises. The Pilot Free Trade Zone will carry out investment project approval and filing, and focus on the investment management work to the pre-approval and turn to process services and post-event supervision, and implement the "double random and open" supervision mode for foreign investment in each area of the Pilot Free Trade Zone. We will fully promote the construction of a "one-stop" comprehensive service platform for foreign investment cooperation, and will be put into operation at the end of September. Relying on the province's first 
provincial-level human resources industrial park, it has established a "one-stop" service platform for overseas talents, and created an "international talent free port" to provide efficient and convenient comprehensive services for enterprises to "go global". Innovative enterprise investment project approval and filing methods, in accordance with the project establishment, planning permission, construction permit, completion acceptance, the Yangling Demonstration Zone explored the establishment of multi-integration, multi-combination, multi-integration, joint assessment, The "three-in-two-link" work mode of joint acceptance has implemented "one-in-one acceptance, parallel approval, and time-limited completion", which drastically reduced the approval time. Establish a full-scale agency system for major project approvals, and implement "one-stop acceptance, full-service agency, and service in the end”. General projects can complete investment licenses within 50 days and start construction.

\section{Conclusion}

Accelerate the construction of the free trade zone in the western region, increase the opening up of the gateway cities in the western region, further implement the strategic cooperation agreement of the western provinces, explore the establishment of foreign trade export production and processing bases, jointly develop the Central Asian and Central and Eastern European markets, and rely on the international festivals of various regions. The platform, such as the Free Trade Zone, will strive to create a new situation in the opening up strategy.

\section{Acknowledgment}

Scientific Research Program Funded by Shaanxi Provincial Education Department (Program No. 17JK0973): "the Belt and Road" Stategic effect on the linkage development of economy in Shaanxi province and remodeling pattern; Xi'an Social Science Fund Project (18J216): Research on the construction of intelligent collaboration platform for Xi'an inland port in ABC era; Shaanxi Provincial Bureau of Statistics Project (LZ201807): Based on the five new concepts to build Shaanxi Datongguan intelligent platform research; Xi'an Translation Institute Research Team Construction Project (XFU17KYTDA02): Industrial docking study of the Silk Road Economic Belt.

\section{References}

[1] Zhang Zhanbin. Trend characteristics and policy orientation of the new normal of Chinese economy [J]. Journal of National School of Administration, 2015(1): 15-16.

[2] Yuan Xintao. National Strategy Analysis of the "Belt and Road" Construction [J]. Theoretical Monthly, 2014(11): 5-8.

[3] Wei Jie, Yang Lin. Industrial restructuring and related reforms under the new economic normal [J]. Economic Aspect, 2015(6): 1-5

[4] Zhu Zhiwen, Yang Jie. Co-construction of the Silk Road Economic Belt and the strategic choice of opening up to the west in the northwest region [J]. Gansu Social Sciences, 2015 (5): 193-197.

[5] Zhou Minliang. Innovative system and mechanism under the background of "Belt and Road" to promote the process of enriching the border and enriching the people [J]. Gansu Social Sciences, 2016(1): 67-71. 